\title{
Evangelicals, then and now: Plausibility, boundaries, and American evangelicalism as ethnicity
}

\section{Brian Steensland}

Although James Davison Hunter was not centrally interested in politics when he began research on American Evangelicalism (Hunter 1983), he captured the evangelical mind-set at the point of evangelicals' political ascent. Hunter was chiefly interested in the dialectic between religion and modernity-specifically the "cognitive bargaining" that takes place when religion accommodates itself to the more powerful forces of modernity. Conceptually, the book identified pluralism as a defining feature of modernity and cast the continuing plausibility of evangelical orthodoxy as the key problematic. His follow-up book, Evangelicalism: The Coming Generation (Hunter 1987) continued this line of inquiry with a focus on young evangelicals in selective evangelical colleges and seminaries. These educational institutions foster the evangelical worldview, but, from Hunter's perspective, also present one of its biggest threats. What Hunter found in both books was a mix of evangelical accommodation and resistance to modernity.

One of Hunter's enduring insights is the importance of placing the challenge of pluralism at the core of analyses of religion. In Charles Taylor's (2007) more recent reconceptualization, modern secularism means that religion is just one of many options. This makes understanding religious plausibility, commitment, and identity in a pluralistic milieu paramount. Hunter's early books provide a model for this agenda. Hunter also sought to forecast the future of evangelicalism. More than 30 years later, data suggest that Hunter correctly anticipated that modernity would continue to erode the plausibility of

This is the author's version of the work published in final form as:

Steensland, B. (2019). Evangelicals, Then and Now: Plausibility, Boundaries, and American Evangelicalism as Ethnicity. Journal for the Scientific Study of Religion, 58(4), 921-924. 
elements of evangelical doctrine. Yet, the symbolic boundaries of evangelicalism, which Hunter suggested would also weaken, remain strong. Evangelicalism's numerical stability, relative coherence, and social influence, despite a weakened adherence to orthodoxy, all suggest that evangelicalism needs to be reconceptualized. In light of recent data and current events, I extend Rogers Brubaker's approach to "ethnicity as cognition" to outline how contemporary American evangelicalism can be understood as an ethnic movement.

\section{Hunter's Analysis of Evangelicals}

Building on the work of Peter Berger, Hunter (1983) argued that the main challenges of modernity for evangelicalism reside in cultural and structural pluralism. Cultural pluralism involves the presence of different and antagonistic worldviews, which generates cognitive dissonance. Structural pluralism means that political, legal, and cultural forces relegate religion to the "private" sphere, which is the remaining place it carries significance and legitimacy. Hunter contended that evangelicals face a choice: They can, in essence, say all religions are true, all religions are false, or only their religion is true. Evangelicals adopt the latter position, but in doing so, they accommodate modernity culturally while resisting it politically. Culturally, evangelicals retain a commitment to doctrinal orthodoxy, but they accommodate by adopting a more civil, if not tolerant, tone in regard to others. Politically, they resist what they view as the decline of traditional morality and the privatization of faith through political mobilization. Through an examination of evangelical books of the era, he found evidence of accommodation and bargaining. Most of the books exhibited a subjectivist turn, focusing more on internal psychological orientations and therapeutic intervention than on the tenets of Christianity. Here, as elsewhere, Hunter made a number of longitudinal claims about changes within evangelicalism, but in the absence of explicit comparisons, it is hard to evaluate their degree. 
Regarding religious plausibility, Hunter's main conclusion was that evangelical plausibility structures remained largely intact due to their distance from modernity. His survey analysis showed that evangelicals were less educated, more rural and southern, and more working class in terms of occupations and income. The implication was that as evangelicals moved toward the social center of modernity, the plausibility of orthodox doctrine would become increasingly enfeebled. One of the chief carriers of modernity, in Hunter's view, was higher education.

This led to Hunter's 1987 book, Evangelicalism: The Coming Generation, which documented the social profile and perspectives of evangelicals attending 16 selective liberal arts colleges and seminaries. He focused on this group to try to anticipate how evangelicalism might look in the future. His soundings, as might be expected, were prescient in some cases and off-target in others, though he cautiously hedged his bets in many places.

Hunter correctly identified two significant trends. He found evidence that evangelicals in elite social locations were moving away from the strict doctrinal orthodoxy of the previous century toward hermeneutical subjectivism and soteriological flexibility. This finding anticipated the "emerging church" movement of the 1990s and the uptake of postmodern epistemologies in swaths of educated, middleclass, knowledge-working evangelicalism (Marti and Ganiel 2014). Notably, Hunter's interpretation of this shift reflects what Taylor (2007) terms a "subtraction" story of loss rather than one that could be described in terms of innovation or transformation. Hunter also found neutral or negative stances toward the Moral Majority and an expanded vision of social responsibility, even while the majority of his sample held conservative views on abortion and homosexuality. Hunter characterized evangelicalism as showing ideological diversity and, in some ways, trending moderate to liberal with an expanded social agenda. This jibes with movements associated with the "new evangelical social engagement" of the 2000s and the finding that roughly a third of evangelicals fit this profile (Green 2014; Steensland and Goff 2014). 
Hunter misidentified some other trends. Concerning group dynamics, he speculated that the symbolic boundaries of evangelicalism would be hard to maintain. Evangelicals would be reluctant to break norms of tolerance and civility; they had weakening commitments to core evangelical doctrines; and, due to the heterogeneity of evangelicalism, there would be less consensus about the boundaries worth enforcing. Concerning politics, because he saw weakened commitment to the Moral Majority, internal heterogeneity, and stronger norms of civility and tolerance, Hunter suggested that evangelicals would be less likely to use the state to advance the evangelical worldview in the public sphere.

So how does Hunter's analysis provide insights into evangelicalism today? We can begin, as Hunter did, with surveys. Data from the Pew Research Center (2015a, 2015b) paints what might look like a paradoxical portrait. Evangelicals have maintained their numerical presence, comprising 25 percent of the American population. Some measures of belief exhibit high levels of doctrinal orthodoxy. Eightyeight percent of evangelicals have absolute confidence in their belief in God and the same percent believe in the reality of heaven. (Perhaps surprisingly from Hunter's perspective, these beliefs do not vary much based on levels of education.) Yet, at the same time, 52 percent of evangelicals say that many religions can lead to eternal life and only 50 percent believe there are clear and absolute standards for right and wrong. When it comes to social boundaries, 48 percent of evangelicals think that immigration makes things worse in society. They have the strongest anti-immigrant views of all religious groups by a large margin, even when compared to Mormons and Jehovah's Witnesses, who are more doctrinally conservative. When it comes to politics, white evangelicals show the strongest support among all religious groups for the public role of churches in public life (Pew Research Center 2014).

We can summarize this portrait in Hunter's terms. In the face of modernity's challenges to religious traditionalism, evangelicalism has retained numerical strength by accommodating cultural pluralism while doubling down on its resistance to structural pluralism and bolstering symbolic boundaries. Evangelicalism's doctrinal core appears firm when it comes to privatized beliefs that pertain to the 
religious self-belief in God, views of the Bible, and reality of heaven. Yet, aspects of Christian doctrine that make claims on others-how others can reach the afterlife, how others should live their life-show considerably lower levels of adherence to doctrinal orthodoxy. Among roughly half of evangelicals, there is private apprehension about the applicability of Christian claims in a pluralistic society, a subjectification consistent with postmodern epistemology. And yet, there is a bold reassertion of the place of religion in public life, a response that works against privatization, though not subjectification. And, there is elevated concern about cultural or racial "others." The reassertion of public, faith-based morality is arguably part and parcel with the weakening of private certainties and an elevated desire for strong symbolic boundaries between evangelicals and out-groups.

\section{American Evangelicalism as an Ethnic Movement}

The public assertions of evangelical Protestants have recently been discussed in terms of "Christian nationalism" - a set of beliefs and ideals based on claims to the country's Christian heritage that are often explicitly evangelical (Whitehead, Perry, and Baker 2018). A more longstanding explanation of evangelical vitality is Smith's (1998) contention that evangelicalism thrives on conflict as a means of reinforcing symbolic boundaries and maintaining subcultural identity. These perspectives inform one another in complementary ways, but they are not coextensive or integrated. Proponents of the Christian nationalism argument seek to make broader claims than those that reduce to evangelical Protestantism. Smith's subcultural identity theory does not focus on race or nation. A step toward an integrated framework treats the animating impulses of mainstream contemporary evangelicalism as an ethnic movement.

Rogers Brubaker and colleagues' perspective on "ethnicity as cognition" provides a starting point (Brubaker, Loveman, and Stamatov 2004). They note the cognitive turn in studies of ethnicity, where ethnicity is seen as a perspective on the world rather than a substance in the world. The shared 
cognitive work that generates an ethnic perspective involves schemas, stereotypes, and social classification. This cognitive work is wedded to cultural projects that bind together ethnicity, race, and nation through collective cultural representations. What is experienced as primordial ethnic affiliation is a product of thick interpretation and discursive claimsmaking based on the categorization of individuals, interactions, and institutions.

Generalizing about a heterogeneous group that comprises a quarter of the American public must be done with caution. But substantial light can be shed on contemporary evangelicalism with these same analytic tools. Hunter closes his 1987 book with a sympathetic diagnosis of the state of evangelicalism. Because modernity undermines orthodox certainties and challenges ontological security, evangelicals find themselves with "no binding address." Similar insecurities can be found in many social groups, of course. The difference is that mainstream evangelical orthodoxy prescribes cognitive certainty and ontological security. An interpretation of the subsequent years is that evangelicals have reasserted claims to a binding address, not based directly on more confident doctrinal certitudes amidst pluralism, but based elliptically on stronger social and symbolic boundaries. These boundaries define their substance. Evangelicalism becomes a "thing of boundaries" (Abbott 1995) rather than a thing with boundaries. To be sure, some of what defines evangelicalism is thin agreement on the rules of engagement (e.g., commitment to Biblical authority) over any substantive agreement on what that authority implies for social life (Markofski 2015). But what we have witnessed in recent years seems to be an evangelicalism defined just as urgently by "primordial" attachments outside the bounds of Christian orthodoxy. Attachment to nation can be seen in the strains of Christian nationalism identified in empirical studies and clearly manifested in evangelical discourse and public ritual. Attachment to race, specifically whiteness, helps account for the strength of anti-immigrant sentiment and continuing majority support for a president who aligns himself with white supremacist individuals and rhetoric. 
Analytically treating mainstream contemporary evangelicalism as an ethnic movement is not reducible to simply noting evangelical symbols and boundaries being grounded in race and nation, though they are significant features. The fuller application of the "ethnicity as cognition" perspective is required. It is also the case that American evangelicalism has always had racist and nativist elements within it. But in this brief essay, acknowledging these connections is a way of both pointing out the contributions of Hunter's analysis and grappling with how the terrain has shifted and how analysts may need to proceed going forward. The seemingly concrete sources of attachment and belonging, located in race and nation, that many evangelicals reach for, and which ironically circumscribe a faith rooted in utterly different ethnic and national origins, appear to enhance certainty and security in the absence of doctrinal confidence undermined by pluralism. This state of affairs stands in stark contrast with a vision of Christianity where citizenship is found in God's kingdom and where earthly community knows no bounds. 


\section{References}

Abbott, Andrew. 1995. Things of boundaries. Social Research 62(4):857-82.

Brubaker, Rogers, Mara Loveman, and Peter Stamatov. 2004. Ethnicity as cognition. Theory and Society 33:31-64.

Green, John C. 2014. New and old evangelical public engagement: A view from the polls. The new evangelical social engagement, edited by Brian Steensland and Philip Goff, pp. 129-53. New York, NY:

Oxford University Press.

Markofski,Wes. 2015. New Monasticism and the transformation of American evangelicalism. New York, NY: Oxford University Press.

Marti, Gerardo, and Gladys Ganiel. 2014. The deconstructed church: Understanding emerging Christianity.New York, NY: Oxford University Press.

Pew Research Center. 2014. Public sees religion's influence waning. Washington, DC, September 22.

-- . 2015a. America's changing religious landscape. Washington, DC, May 12.

- - -2015b. U.S. public becoming less religious. Washington, DC, November 3.

Smith, Christian. 1998. American evangelicalism: Embattled and thriving. Chicago, IL: University of Chicago Press.

Steensland, Brian, and Philip Goff (Eds.). 2014. The new evangelical social engagement. New York, NY: Oxford University Press.

Whitehead, Andrew L., Samuel L. Perry, and Joseph O. Baker. 2018. Make America Christian again: Christian nationalism and voting for Donald Trump in the 2016 election. Sociology of Religion 79(2):14771. 